\title{
A Contradiction of the Existence of English in Rural and Urban Pesantren
}

\section{in Indonesia}

\author{
Mochamad Imron Azami, Imron.azami@unisma.ac.id, English Department, Faculty of \\ Education and Teacher Training, University of Islam Malang, Indonesia
}

\begin{abstract}
Pesantren emphasizes the learning of religious knowledge based on the classical textbook given to santri (student). Nowadays, pesantren shifts its tradition by providing English programs. This shifting occurs as the effort of pesantren to face the challenges of modernization and fulfilsociety's demands. The aim of this research is to compare the adjustment of pesantren in applying for the English program as their reform in rural and urban pesantren. This study used a comparative study by using semi-structured interviews with the chief of the English program and distributed to 142 entries in both pesantren. The result showed that the existence of English programs in pesantren, both in rural and urban areas, was because of the demand of the society. In rural pesantren, the reason why they provided an English is because they wanted to develop the society surrounded pesantren, which are Indonesian Migrant Worker (Tenaga Kerja Indonesia). While in an urban area, they provided an English program because they were focusing on the development of sentries themselves to prepare for the global community.
\end{abstract}

Keywords: English teaching, pesantren"' reform, urban area, rural area.

\section{INTRODUCTION}

Pesantren is the oldest traditional Islamic education system that still exists in this millennium era in Indonesia. These pesantren had become the local wisdom of Indonesia and could not be found in any other places in the world. The word pesantren has a long-related history with the widespread of Islam in Indonesia. Islam had spread widely in the early $13^{\text {th }}$ century. The spreading was mainly through Islamic teaching in the form of Quranic study in the village mosque, prayer house, and the private home community conducted and taught by religious teachers (Hefner and Zaman, 2007). The classic style of teaching become the beginning of Islamic teaching in the form of non-formal education institutions in Indonesia. Historically, pesantren, as a traditional institution, was strongly related to Islamic education with its traditional teaching (Wahid, 2001).

The words pesantren are used differently in every region in Indonesia that is still related to that traditional Islamic educational institution. The basis of pesantren in Indonesia was in Java Island. Still, the other areas have their term to call pesantren, such as the term pesantren used in Java, Surau in West Sumatra, Dayah in Aceh. All these terms used are related to traditional Islamic education institutions in Indonesia (Azra, 2014).

The word pesantren originally comes from the phrase santri that added the prefix ""'Pe""'" and suffix "'"'An"'" written as pesantrian. As time passed, the phrase pesantren becomes pesantren as it is easier to pronounce. Furthermore, the phrase santri comes from Sastri (Hindis), which means a Hindish holy book expert. Due to BahasIndonesia's

36 | IJET| Volume. 10, Issue 1. July 2021

Copyright 2021 Mochamad Imron Azami is licensed under Creative Commons Atrribution-ShareAlike 4.0 International License. 
assimilation and meaning shift, the word santri changed its meaning to Islamic holy book expert (Departemen Agama Republik Indonesia, 2004).

Etymologically, "'""pesantren"'"'" and the original word "'"santri"'"'" come from the Tamil language meaning ""'religious teacher."'" In short, pesantren is the traditional Islamic education institution for santri to learn religious lessons under the guidance of Kyai. Nowadays, the usage of pesantren in Indonesia today combining two terms of "'"'pondok"'"'" (from the Arabic language: barrack or hotel) and "'"pesantren"'"'" mostly can be interchangeable, even can be merged into "'"Pondok pesantren,"'"'" which usually can be shortened into "'"'ponpes"'"'" (Mansurnoor, 1990). It means every santri must stay into Pondok pesantren to learn a religious lesson from Kyai. In short, pesantren is the traditional Islamic education institution for santri to learn Islamic knowledge under the guidance of Kyai (the leader of the pesantren).

At the beginning of the establishment, pesantren was more emphasizing on the Salafi system. The learning process focused on religious learning based on ""'old books""" (Kitab kuning). The old books were usually written by a Muslim scholar, Shāfi $\overline{1}$. The books comprised of Arabic grammar (naḥw) and conjugation (șarf), Qur'ānic recitation (qirā'ah), Qur'ānic exegesis (tafsìr), theology (tawhìd), jurisprudence (fiqh), ethics (akhlāq), logic (manțiq), history (tārikkh) and mysticism (tașawwüf) (Federspiel, 2017). Due to time passing and the high demand from society, people have decreased of their interest in the Salafi system. From a personal interview with one of the Kyai in Pesantren Nazhatut Thullab in Sampang Madura, it is understood that many of Salafi pesantren in Indonesia has decreased in numbers of santri. The closing pesantren was due to the lack of Salafi system needs from nearby society.

The existence of pesantren had numerous challenges and restrictions since the Netherlands"' colonialism until the present day. In the colonial era, the colonial government of the Netherlands introduced the new system of education for children by establishing Sekolah Rakyat (Volkscholen), or to be called Sekolah Dasar (Nagari), with three years period of time (Madjid, 1997). With thiinstitution's existence, the existence of pesantren was somehow decreasing due to societal preference for Sekolah Rakyat over pesantren. Moreover, in the early $20^{\text {th }}$ century, Muslim reformists made a renewal of Islamic education in the form of (1) giving Islamic education in the formal School; (2) building modern Madrasah, which limited to the adoption of the modern school system (Madjid, 1997).

Due to these cases, many pesantren tend to provide the formal education institution inside the pesantren. Nonetheless, ideally, society needs religious knowledge acquisition and access to formal education aimed towards the attainment of vocational certificates or diplomas (Madjid, 1997). Although pesantren is usually known as conservative Islamic tradition that is secured from the renewal education system, pesantren is not merely comprised of Islamic teaching and Salafi system. Still, it also contains indigenous of Indonesia (Madjid, 1985).

Therefore, pesantren made some adjustment steps that brought advantages for santri, supported the continuity of pesantren, and developed its education such as grading system and comprehensive curriculum (Azra, 1998). Therefore, there were two factors (internal and external) that influenced the education system in pesantren (Qodir, 2006). Internal factors were from the modernization and secularization of Islamic education in the context of working orientation for santri. External factors were from changing global influence by the development of technology and information.

37 | IJET| Volume. 10, Issue 1. July 2021

Copyright 2021 Mochamad Imron Azami is licensed under Creative Commons Atrribution-ShareAlike 4.0 International License. 
The transformation of pesantren arises to encounter the modernization of Islamic education. Firstly, the pesantren education system is taught the classical book and taught the modern subject Secondly, common pesantren arises and develops in a rural area, but now, abundant pesantren arises in urban areas. Thirdly, in rural areas, society has known the term "'"'Kyai Nasab.""'" On the contrary, the urban areas arise the term "'"Kyai Nasib,"'"' who has mastering Islamic studies and has good administrative skills to manage pesantren (Shodiq, 2011).

Based on the perspective of openness and changing (Zamakhsyari, 1982), pesantren can be divided into two categories: Pesantren Salafi and Pesantren Khalafi. Pesantren Salafi is a traditional pesantren that focuses on studying classical text or book (Kitab kuning). On the other hand, Pesantren Khalafi is a modern pesantren that establishes a regular school, Madrasah Dinniyah (Salafi system), Higher Education, and Takhassus (Arabic and English) (Nasir, 2005).

Furthermore, the positive trend of English usage in pesantren was also supported by thresearcher's pilot study. Four hundred sixty-three students of the English Teacher Education Department in the State Islamic University of Sunan Ampel Surabaya were interviewed by the researcher. And the result was there were 101 students from 463 students who graduated from pesantren. It means that many of santri from pesantren want to continue their study at the university and prefer to choose English as their major.

Many kinds of literature in terms of English program in pesantren were emphasized more on English teaching method than the historical background of the adjustment of English program in pesantren. Furthermore, applying English in pesantren is essential to know the fundamental reason for the implementation of English in pesantren both in rural and urban areas. Moreover, study on the perspective from santri towards English program will guide us to comprehenEnglish's objective in pesantren. Therefore, this study was never done before by the other researcher who works in English that only focused on the English teaching method in pesantren.

Nowadays, many pesantren give the best effort to provide English in their curriculum. Nevertheless, this case is contrary to the main purpose of establishing pesantren as the center of Islamic studies based on the classical textbook. Pesantren Nazhatut Thullab in Sampang Madura and Pesantren Progresif Bumi Shalawat (for further, both pesantren will be used acronym as PNT for Pesantren Nazhatut Thullab and PPBS for Pesantren Progresif Bumi Shalawat) are the examples that offers English subject for santri. Moreover, one of these pesantren also adapts Cambridge curriculum to improvsantri's ability in English. From this case, the researcher was interested in observing three aspects, including the reasons of pesantrens'" shift to provide English, the aims of the shifting it, and the response of sentries towards English in pesantren.

\section{METHOD}

This study used a comparative approach as the research design. Comparative research belongs to the term of evaluation for similarities, differences, and associations of entities or variables (Mills, 2008). In this study, the comparative framework is used to compare two different educational systems between urban pesantren and rural pesantren. The meaning of educational system shifting in pesantren is the mechanism and procedure of changing the curriculum from Salafi system to Khalafi system by providing English in pesantren. This study is emphasized the pesantren which applied the Khalafi system concerning the

38 | IJET | Volume. 10, Issue 1. July 2021

Copyright 2021 Mochamad Imron Azami is licensed under Creative Commons Atrribution-ShareAlike 4.0 International License. 
development of the English program and students"' responses towards the English program in pesantren.

The researcher used interview guidelines with a semi-structured interview with 2 chiefs of the English program in both pesantren to gather the data about the history of English program implementation, as well as establishment consideration. An open-ended interview is a common type that is often used by the researcher in the qualitative approach. Silverman (2000) argued that the choice of an open-ended interview (semi-structured) is a gold standard of qualitative research. On the other hand, an open-ended question is a kind of question that researchers pose to research participants and allow them to select their position towards the research topic (Roulston, 2008). In this study, the use of open-ended questions was formed in the term of questionnaire to collect the data about sentries responses towards English education teaching in pesantren.

The researcher selected two pesantrens: Pesantren Progresif Bumi Shalawat (PPBS) in Sidoarjo East Java as urban pesantren and Pesantren Nazhatut Thullab (PNT) in Sampang Madura as rural pesantren. The reason for choosing both pesantren was because they provided the English Program in pesantren. Besides, personally, the researcher had an immense interest in comparing the English curriculum between the two pesantrens as they had a different English curriculum. PNT adopted the local curriculum, while PPBS adopted the international curriculum.

Thistudy's participants are 2 heads of the English program and 142 santries, including 53 santries from PNT and 89 santries from PPBS. The researcher distributed the questionnaire to 142 santries, including 53 santries from PNT who joined Nata English Club (NEC) program and 89 santries from PPBS who joined the Cambridge class. Afterward, the researcher interviewed the head of the English program to gain data about the usage of English in pesantren. In this situation, the researcher also interviewed some staff in pesantren who witnessed the history of the English program implementation.

\section{RESULT AND DISCUSSION}

In this context, there are huge different systems applied by rural and urban pesantren in terms of the development of the English program. In the early establishment of the English program, both pesantren have different aims to be achieved in English program. Either for the cooperation to develop the English program itself, they conducted the collaboration with some institutions. The last, pesantren in rural area pretends to choose the local curriculum from English courses, and pesantren in the urban area applied international curriculum. Those cases will be discussed below.

Table 1. Comparative Framework of English Program between PNT and PPBS

\begin{tabular}{|c|c|c|}
\hline Variable & PNT & PPBS \\
\hline The Aim of the English & To facilitate student who & To prepare them before \\
\hline Program Establishment & has potential in the English & $\begin{array}{l}\text { applying the English } \\
\text { international curriculum }\end{array}$ \\
\hline Cooperation & $\begin{array}{l}\text { 1. Pesantren Al-Amien } \\
\text { Sampang } \\
\text { 2. Bhineka Language } \\
\text { Institution } \\
\text { 3. Al-Fattah English }\end{array}$ & $\begin{array}{l}\text { 1. Common European } \\
\text { Framework of Reference } \\
\text { for Language Concept } \\
\text { (CEFR) } \\
\text { 2. Cambridge International }\end{array}$ \\
\hline
\end{tabular}

39 | IJET $\mid$ Volume. 10, Issue 1. July 2021

Copyright 2021 Mochamad Imron Azami is licensed under Creative Commons Atrribution-ShareAlike 4.0 International License. 
Course (AEC)

Curriculum
1. Al-Fattah English

Course (AEC)
Examination (CIE)

3. Act Edu Solution

1. Cambridge Curriculum (EFL)

2. Act Edu Solution (EPP)

English program provided in PNT started in the $9^{\text {th }}$ generation by KHMu'afi Alif Zaini. In a different location, PPBS provided the English program in 2012, along with the establishment of a new branch pesantren. At the beginning of the English program establishment, PNT provided English courses without any formal name and was not obligatory for students. This course provided to potential santries who are interested in learning English.
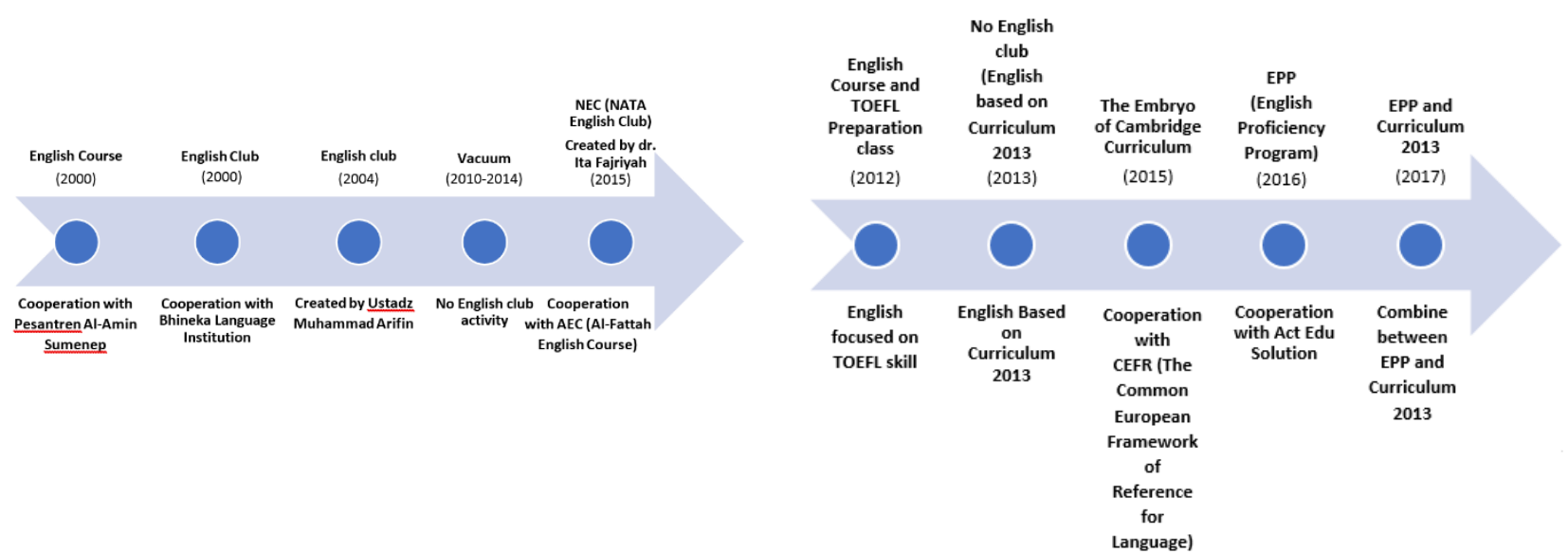

Figure 1. Comparative Development of English Program in PNT and PPBS

Pesantren Progresif Bumi Shalawat provided the English course and TOEFL Preparation class for santries to prepare them before applying the international curriculum. The concept of an integrated curriculum (combining international curriculum and national curriculum) was already planned by the owner of pesantren before establishing a new branch of PPBS. The preparation was conducted by inviting many Muslim scholars, Kyai from other pesantren and some Professors from the university. From this case, the pesantren provided both English course and TOEFL preparation class to enhance santries basic knowledge in English. Thus, they were prepared to face the international curriculum.

In terms of the partnership, PNT collaborates with some local institutions to support the English program in pesantren. Those institutions were Pesantren Al-Amien Sampang, Bhineka Language Institution, and Al-Fattah English Course (AEC). The cooperation was to provide English teachers and to adopt the curriculum from those institutions.

On the other hand, PPBS cooperated with an international institution to reach its vision. The vision was curriculum integration anpesantren's internationalization. PPBS had a cooperated with the Common European Framework of References for Language Concept (CEFR) for applying the Cambridge Curriculum. The other cooperation was with Act Edu Solutions. The partnership was to provide English Proficiency Program (EPP) along with 
Cambridge Curriculum, which focused on English For Literature (EFL). This cooperation was primarily prepared to support English learning in pesantren, which also fitted with the national curriculum.

In conclusion, the aim of providing an English Program in PNT is to facilitate potential santries to learn English. Meanwhile, PPBS provided English courses to prepare santries before applying the International Cambridge curriculum anpesantren's internationalization.

\subsection{Students' Responses towards English Program in Pesantren Nazhatut Thullab and}

\section{Pesantren Progresif Bumi Shalawat}

In this part, the researcher distributed an open-ended questionnaire to 142 santries, including 53 santries from PNT and 89 santries from PPBS. An open-ended questionnaire in this research was to gather data about santries" "responses towards the English program. The responses were mainly about three aspects: the differences between learning English in pesantren and School, the aim of learning English in pesantren, and their expectation of English program in pesantren.

\subsection{Santri Response towards the Reason of Learning English in Pesantren}

There were similar answers to the first question, which asked santries'" responses towards learning English in both pesantren. The first reason for learning English in pesantren based on countries' answers in both pesantren was for the future orientation. $28 \%$ santries in PNT argued that learning English was important for them in working orientation and studying abroad. These opinions might influencsociety's mindset in Sampang, who as numerous people in the city, work as Indonesian migrant workers. Afterward, santries were also influenced by some ustadz or teacher in pesantren who studied abroad such as in Yemen. Thepesantren'ss Kyai has already gone to some countries such as Singapore, Yemen, Germany, and Japan. Therefore, the santries thought that the reason for learning English in pesantren was for working and studying abroad. Moreover, 9\% santries of PPBS considered that English as a tool to ease getting a job and studying abroad.

Table 2. Santri Response about the Reason on Learning English in Pesantren

\begin{tabular}{lll}
\hline Santries" answer & PNT & PPBS \\
\hline $\begin{array}{l}\text { For future (working orientation, study } \\
\text { abroad) }\end{array}$ & $28 \%$ & $9 \%$ \\
$\begin{array}{l}\text { International language } \\
\text { English is essential for santries }\end{array}$ & $28 \%$ & $24 \%$ \\
$\begin{array}{l}\text { English also is provided in pesantren } \\
\text { For communication purpose }\end{array}$ & $24 \%$ & $16 \%$ \\
\hline
\end{tabular}

Afterward, both santries in PNT and PPBS had the same answer because English is an international language ( $28 \%$ santries of PNT and 24\% santries of PPBS). The common mindset for santries both in rural and urban pesantren was that English is an international language. Additionally, the majority of santries in PPBS said that English was important to be learned in pesantren. Learning English was useful to stay updated. Some of the santries also added that PPBS was International pesantren; thus, they should learn English.

41 | IJET| Volume. 10, Issue 1. July 2021

Copyright 2021 Mochamad Imron Azami is licensed under Creative Commons Atrribution-ShareAlike 4.0 International License. 
On the other hand, some students in both pesantren, including 8\% santries in PNT and $11 \%$ santries from PPBS, were argued why pesantren provided English in pesantren. The argument was based on the stereotype that pesantren was a place for studying Islam, not English. Furthermore, there was some benefit for santries when they were learning English in pesantren. As said by santries in both pesantren, 6\% santries in PNT and 2\% santries in PPBS, they could practice speaking in English with their friends in dormitory. Typically, santries were obligated to stay in the dormitory as they studied in pesantren.Santries" Opinion about the Differences in Learning English in Pesantren and School

As the researcher mentioned above about the benefit of learning English in pesantren, the differences between learning English in pesantren and School were that School offered a theory to students, and pesantren provided a chance for santries to practice. $43 \%$ santries in PNT and 16\% santries in PPBS had the same answer. This notion was also supported by the answer from $11 \%$ santries in PNT and 31\% santries of PPBS. Santries believed that pesantren had allocated more time, compared to regular School. In PNT, santries learned English 3 times a day. In contrast, regular Schools limited the time for learning English based on the national curriculum.

Table 3. Santries Opinions about The Differences in Learning English in pesantren and School

\begin{tabular}{|c|c|c|}
\hline Santries answer & PNT & PPBS \\
\hline $\begin{array}{l}\text { School teach English based on } \\
\text { material, pesantren combine } \\
\text { practice and material }\end{array}$ & $43 \%$ & $16 \%$ \\
\hline $\begin{array}{l}\text { Pesantren more detail than } \\
\text { School }\end{array}$ & $15 \%$ & \\
\hline Same, nothing different & $11 \%$ & $31 \%$ \\
\hline $\begin{array}{l}\text { Pesantren has plenty of time } \\
\text { than School }\end{array}$ & $11 \%$ & $16 \%$ \\
\hline
\end{tabular}

There were $11 \%$ santries of PNT and $31 \%$ santries of PPBS said that there was no difference in learning English, both in pesantren and in regular School. This answer was contrary to the previous answer by santries both in PNT and PPBS. In the case of PNT, the researcher argued as the teaching material of English in both pesantren, and regular Schools was the same. Therefore, this reasoning might be the justification for this answer.

On the other hand, santri in PPBS might be confused with the concept of curriculum integration. In this context, the English program at the beginning of the establishment was more focusing on pesantren. Afterward, the focus was changed when the pesantren applying the Cambridge curriculum. The curriculum emphasizes English learning in regularSchool, rather than in pesantren. Thus, $6 \%$ of santries in PPBS considered that they learned English in School.

\subsection{Santri Opinion about the Aim of Learning English in Pesantren}

The third question was regarding the aim of learning English in pesantren. $40 \%$ of santries in PNT and 21\% santries in PPBS said that pesantren provided an English program to create santries who were able to speak in English. Additionally, 32\% of santries in PPBS that

42 | IJET| Volume. 10, Issue 1. July 2021

Copyright 2021 Mochamad Imron Azami is licensed under Creative Commons Atrribution-ShareAlike 4.0 International License. 
said to create modern santri who can speak English, added their opinion with" not backward with the development of Tim"'".

Table 4.Santries" Opinion about The Aim of Learning English in Pesantren

\begin{tabular}{lll}
\hline Santries" answer & PNT & PPBS \\
\hline To create santries who can speak & $40 \%$ & $21 \%$ \\
English & & \\
To introduce English to santries & $24 \%$ & \\
for future & $11 \%$ & $24 \%$ \\
To create modern santries (not left & & $32 \%$ \\
behind) & & $11 \%$ \\
To improvesantries" ability in & & \\
English & & \\
\hline
\end{tabular}

Afterward, 2\% of santries from PNT and 9\% santries from PPBS said that English is an international language. In this context, santri in both pesantren attempted to answer that English was not just provided in the School, but pesantren also tried to give English for santries. Furthermore, this context also had an impact on them after they graduated from pesantren. Thus, $11 \%$ of santries in PNT and 24\% of santries in PPBS said that learning English in pesantren was to help them get a job and study abroad.

There were 6\% santries in PNT, and 2\% santries in pesantren PPBS said that the aim of learning English in pesantren was to give them English ability to compete with other pesantren or School. In the past, there was such a societal paradigm that santries who graduated from pesantren just comprehend religious knowledge and cannot compete with the student who graduated from regular School. But nowadays, the paradigm shifts slowly with the reformation of pesantren by providing English as a tool for santri to survive and compete.

\section{Santries" Expectation for English Learning in Pesantren}

In the last question in the open-ended questionnaire, both santries in PNT and PPBS have the same expectation for the English program in pesantren. There were $68 \%$ santries in PNT, and $72 \%$ santries in PPBS said that they wished English Program in pesantren can develop well. But they had different expectations towards English Program in each pesantren.

Table 5.Santries" Expectation for English Learning in Pesantren

\begin{tabular}{lll}
\hline Reason & PNT & PPBS \\
\hline $\begin{array}{l}\text { English program in pesantren can } \\
\text { develop }\end{array}$ & $68 \%$ & $72 \%$ \\
$\begin{array}{l}\text { Santries can speak English very } \\
\text { well }\end{array}$ & $9 \%$ & \\
$\begin{array}{l}\text { Pesantren can develop through an } \\
\text { English program }\end{array}$ & $9 \%$ & \\
$\begin{array}{l}\text { Can develop entries" ability in } \\
\text { English }\end{array}$ & & $10 \%$ \\
$\begin{array}{l}\text { Santries and Ustadz(teacher) can } \\
\text { speak English fluently }\end{array}$ & $7 \%$ \\
\hline
\end{tabular}

43 | IJET| Volume. 10, Issue 1. July 2021

Copyright 2021 Mochamad Imron Azami is licensed under Creative Commons Atrribution-ShareAlike 4.0 International License. 
Santries in PNT is expected that the English Program in pesantren can develop in the case of the professional teacher, materials, and facilities. Nonetheless, there were some obstacles during the English program development in PNT. Several teachers of the English Program in PNT were not graduated from the English department. Even some English teachers were still studying at university. Subsequently, sometimes they were absent from teaching in pesantren. And for material, PNT is still adopting curriculum or textbooks from other institutions. Hence, this case might do not cover the English needs for santries in pesantren. Moreover, PNT had few facilities to support the English program in pesantren. Some English teachers just used the textbook and emphasized more on lecturing than innovative learning.

On the other hand, santries in PPBS expected that pesantren should provide more outdoor learning, English camp and invite more native English speakers. Outdoor learning meant that santries could study outside the classroom to learn some material related to their surroundings. This kind of activity successfully attracted thesantries" interest to learn English. Besides, pesantren also provided an English camp for santries based on English Special Purposes (ESP) as a program to develop their English ability, based on the context of surroundings.

Furthermore, santries in both pesantren (9\% santries from PNT and 7\% santries from PPBS) stated that through English Program provided by pesantren, they expected an improvement in English ability. As a result, English was able to be used in pesantren as a means of instruction and Arabic. The santries also expect that through English Program, it can help them to reach their dreams, such as studying abroad. Many santries in both pesantren had a strong desire to continue their study to a higher degree abroad. This means that santries nowadays are not santries in the past who left behind and cannot compete with others. Through some reformation that was done by pesantren, such as English program, santries can compete in the modern era.

\section{CONCLUSION}

The existence of English programs in pesantren, both in rural and urban areas, was because society's demand. In rural pesantren, the reason why they provided English is because they wanted to develop the society surrounding pesantren, which are Indonesian Migrant Worker (Tenaga Kerja Indonesia). While in an urban areas, they provided an English programs because they focused on developing countries themselves to prepare for the global community. On the other hand, in thesantries" perspective about English program in pesantren, they were agreed that santries nowadays should not be conservative. They started to recognize that scientific knowledge was as important as religious knowledge. Additionally, both santries in urban and rural areas had the same hope; English programs in pesantren must be developed to facilitate santries who want to learn English in pesantren.

However, this research only used 2 pesantren as a comparison to gathering the data about the English programs in pesantren. For more various data, the researcher suggests to the future research to apply more pesantren in the rural and urban area in their study to discover any possible variant data about the application of English in pesantren. Furthermore, this study only used pesantren, is in the East Java region. Although, there are several pesantren existed in all around Indonesia which has their own uniqueness and characteristic in providing English program in their pesantren based on the demand of the society surrounded pesantren. This condition is also a consideration for future work to use more pesantren outside East Java.

44 | IJET| Volume. 10, Issue 1. July 2021

Copyright 2021 Mochamad Imron Azami is licensed under Creative Commons Atrribution-ShareAlike 4.0 International License. 


\section{REFERENCES}

Azra, Azyumardi. 1999. Esei-Esei Intelektual Muslim Dan Pendidikan Islam. Logos Wacana Ilmu.

Azra, Azyumardi. 2014.""Reforms in Islamic Education: A Global Perspective Seen from the Indonesian Case"" TAN (Ed.) 2014: 59-75.

Babapour, Maryam, Saeideh Ahangari, and Touran Ahour. 2019.""The Effect of Shadow Reading and Collaborative Strategic Reading on EFLLearners" Reading Comprehension across Two Proficiency Levels"" Innovation in Language Learning and Teaching 13, no. 4: $318-30$.

Departemen Agama, R I. 2004. "Grand Desain Pendidikan Keagamaan Dan Pondok Pesantren.” Jakarta: Direktorat Peka Pontren Pada Ditjen Bagais Dep. Agama.

Hefner, Robert. 2008.""2. Islamic Schools, Social Movements, and Democracy in Indonesia"" In Making Modern Muslims, 55-105. University of Hawaii Press.

Ismail, Muchammad. 2011. "Pesantren Dan Perubahan Sosial." The Sociology of Islam 1, no. 1.

Madjid, Nather, Elin Elvander Tottie, Maria Lüttgen, Björn Meister, Johan Sandin, Alexander Kuzmin, Oliver Stiedl, and Sven Ove Ögren. 2006.""5-Hydroxytryptamine 1A Receptor Blockade Facilitates Aversive Learning in Mice: Interactions with Cholinergic and Glutamatergic Mechanisms"" Journal of Pharmacology and Experimental Therapeutics 316, no. 2: 581-91.

Madjid, Nurcholis. 1997. Bilik-Bilik Pesantren: Sebuah Potret Perjalanan. Paramadina.

Mansurnoor, Iik Arifin. 1990. Islam in an Indonesian World: Ulama of Madura. Gadjah Mada University Press.

Nasir, M Ridlwan. 2005. Mencari Tipologi Format Pendidikan Ideal: Pondok Pesantren Di Tengah Arus Perubahan. Pustaka pelajar.

Nugroho, Arif, and Agnira Rekha. 2020.""Speech Acts of Requests: A Case of Indonesian EFL Learners"" Journal of English Language Teaching and Linguistics 5, no. 1: 1-16.

Qodir, Zuly. 2006. Pembaharuan Pemikiran Islam: Wacana Dan Aksi Islam Indonesia. Pustaka Pelajar.

Roulston, Carli L, Jennifer K Callaway, Bevyn Jarrott, Owen L Woodman, and Gregory J Dusting. 2008."'Using Behaviour to Predict Stroke Severity in Conscious Rats: PostStroke Treatment with 3', 4'-Dihydroxyflavonol Improves Recovery"' European Journal of Pharmacology 584, no. 1: 100-110.

Wahid, K H Abdurrahman. 2001. Menggerakkan Tradisi; Esai-Esai Pesantren. LKIS PELANGI AKSARA. 